\title{
Titanium Implant Surface Modification in Physiological Serum Containing New Mixed Inhibitor Based on Poly(vinyl) Alcohol/Silver Nanoparticles/Epirubicin
}

\author{
Adriana Samide $^{1 *}$, Simona Iordache ${ }^{1}$, Gabriela Eugenia Iacobescu ${ }^{2}$, Cristian Tigae ${ }^{1}$, Cezar Spînu ${ }^{1}$ \\ ${ }^{1}$ University of Craiova, Faculty of Sciences, Department of Chemistry, 107i Calea Bucuresti, Craiova, \\ Romania \\ ${ }^{2}$ University of Craiova, Faculty of Sciences, Department of Physics, A.I. Cuza, no.13, Craiova, \\ Romania \\ *E-mail: samide_adriana@yahoo.com
}

doi: $10.20964 / 2018.12 .61$

Received: 25 August 2018 / Accepted: 1 October 2018 / Published: 5 November 2018

\begin{abstract}
The titanium behaviour in physiological serum blank (PS) and containing silver nanoparticles (nAg) and polyvinyl alcohol (PVA) in the absence and presence of epirubicin cytostatic (EPR) was studied by potentiodynamic polarization and electrochemical impedance/admittance spectroscopy. These showed that the electrochemical parameters classically ranged, meaning that the addition of nAg/PVA and epirubicin in physiological serum leads to corrosion current density decline and polarization resistance increase while the conductance is diminished. The induced modifications on titanium surface were highlighted by optical microscopy and atomic force microscopy (AFM) which displayed the specific coating adsorbed on titanium surface. Consequently, nAg/PVA improves the epirubicin effect on titanium surface. Prior to the measurements above mentioned, the interactions between $\mathrm{nAg}$ and PVA were studied, showing the nAg/PVA composite formation. Also, the interactions between $\mathrm{Cl}^{-}$ ions, epirubicin and $\mathrm{nAg}$ were discussed, in order to better understand the influence of $\mathrm{nAg} / \mathrm{PVA}$ composite on the epirubicin protective performance on the titanium surface.
\end{abstract}

Keywords: titanium bioimplant; silver nanoparticles/poly(vinyl) alcohol composite; epirubicin cytostatic; electrochemical measurements; AFM

\section{$\underline{\text { FULL TEXT }}$}

(C) 2018 The Authors. Published by ESG (www.electrochemsci.org). This article is an open access article distributed under the terms and conditions of the Creative Commons Attribution license (http://creativecommons.org/licenses/by/4.0/). 